\title{
Immunosuppressive constituents from an Ascomycete, Sordaria gondaensis
}

\author{
Haruhiro FUJIMOTO, Toshiyuki FUJIMAKI, \\ Emi OKUYAMA and Mikio YAMAZAKI \\ Faculty of Pharmaceutical Sciences, Chiba University \\ (1-33, Yayoi-cho, Inage-ku, Chiba 263-8522, Japan)
}

\begin{abstract}
Summary
Immunomodulatory activity-guided fractionation of the ethyl acetate extract of an Ascomycete, Sordaria gondaensis, afforded three dioxopiperazine-type constituents as the immunosuppressive features of this fungus. They were elucidated to be two known fungal metabolites, tryprostatin $\mathrm{B}$ and fumitremorgin $\mathrm{B}$, and a new metabolite 13-oxofumitremorgin $\mathrm{B}$ by their physicochemical and spectral data and the chemical correlation. This is the first time that both tryprostatin $B$ and fumitremorgin $B$ have been isolated from this fungus.
\end{abstract}

Key words : Sordaria gondaensis, Ascomycete, immunosuppressant, 2,5-dioxopiperazine, 13-oxofumitremorgin B

(Received, March 3, 2000, Revised \& Accepted April 3, 2000)

\section{Introduction}

In our recent search for immunomodulatory components from Ascomycetes, several novel immunosuppressants from Gelasinospora multiforis, ${ }^{1,2)}$ G. kobi, ${ }^{3)}$ G. heterospora, ${ }^{2)}$ G. longispora, ${ }^{2)}$ Diplogelasinospora grovesii, ${ }^{4)}$ and Microascus tardifaciens ${ }^{5)}$ were isolated. Continuously, it was found that the ethyl acetate (AcOEt) extract of Sordaria gondaensis IFM4583 ${ }^{6}$ ) suppressed significantly proliferation (blastogenesis) of mouse splenic lymphocytes stimulated with mitogens, concanavalin A (ConA) and lipopolysaccharide (LPS). Immunomodulatory activity-guided fractionation of the extract by solvent partition and chromatographic separation afforded three metabolites tentatively named SG1 (1), -2 (2), and -3 (3) as the immunosuppressive features of this fungus. This report deals with the structure and immunosuppressive activity of these metabolites.

\section{Materials and Methods}

The general procedures for chemical and other experimental conditions, including those for the evaluation of immunomodulatory activity of samples against mouse splenic lymphocytes stimulated with Con A and LPS, were the same as described in our previous report [this method is based on the formation ratio of formazan from exogenous 3-(4,5-dimethyl-2-thiazolyl)-2,5-diphenyl-2H-tetrazolium bromide (MTT) in lymphocytes]. ${ }^{2)}$ The thin layer chromatography (TLC) was carried out with Merck Kieselgel $60 \mathrm{~F}_{254}$ (ordinary phase) and/or RP18 $\mathrm{F}_{254} \mathrm{~S}$ (reverse phase) plates and an ultraviolet (UV) 
detector at 254 and $360 \mathrm{~nm}$. The infrared (IR) spectra, the UV spectra, the circular dichroism (CD) spectra, the electron impact mass spectra (EI-MS), the high-resolution EI-MS (HREI-MS), and the optical rotations were recorded with a JASCO FT-IR230, a Hitachi U-3200, a JASCO J-500, a Hitachi M60, a JEOL JMS-HX110A, and a JASCO DIP-140 spectrometers, respectively. The ${ }^{1} \mathrm{H}$ - and ${ }^{13} \mathrm{C}$-nuclear magnetic resonance (NMR) spectra were recorded in deuterochloroform $\left(\mathrm{CDCl}_{3}\right)$ with a JEOL JNMA400 or JNM-A500 spectrometer in $\delta(\mathrm{ppm})$ values from tetramethylsilane (TMS) as an internal standard at 400 and $100.4 \mathrm{MHz}$, or at 500 and $125.65 \mathrm{MHz}$, respectively.

Isolation of SG-1 (1), -2 (2), and -3 (3) Black or dark greenish brown colored mycelia of Sordaria gondaensis IFM45836) cultivated on sterilized rice media $(200 \mathrm{~g} /$ flask $\times 50)$ at $25^{\circ} \mathrm{C}$ for 29 days were extracted with AcOEt (15 l) with shaking at room temperature for 5 hours two times to give an extract (after evaporation in vacuo, $32.3 \mathrm{~g}$ ), which was then suspended in water $(300 \mathrm{ml})$. The aqueous suspension was shaken with $n$-hexane $(300 \mathrm{ml})$ two times to separate $n$-hexane-soluble portion (after evaporation in vacuo, $18.7 \mathrm{~g}$ ), and then partitioned with AcOEt $(300 \mathrm{ml})$ two times into AcOEt layer (after evaporation in vacuo, $11.3 \mathrm{~g}$ ) and aqueous layer (after lyophilization in vacuo, 1.8 g). The AcOEt layer was subjected to silica gel column chromatography with $\mathrm{CHCl}_{3}-\mathrm{MeOH}$ to give six fractions I - VI. Fraction III (2.97 g) was then chromatographed on an octadecyl silica gel (ODS) column with $\mathrm{MeOH}$ and $\mathrm{CHCl}_{3}$ to give $\mathrm{MeOH}$-soluble fraction (Fraction IIIm) $\left(1.25 \mathrm{~g}\right.$ ) and $\mathrm{CHCl}_{3-}$ soluble fraction (Fraction III c) (111 mg). Fraction $\mathrm{Il} \mathrm{m}$ was further chromatographed on an ODS column with $\mathrm{H}_{2} \mathrm{O}-\mathrm{MeOH}(3: 2, \mathrm{v} / \mathrm{v}), \mathrm{MeOH}$, and $\mathrm{CHCl}_{3}$ to give six fractions IIIm1- Ill $\mathrm{m} 6$. Fraction III $\mathrm{m} 3$ afforded 1 (476 mg) directly after evaporation of the solvent. Fraction III $\mathrm{m} 4(80 \mathrm{mg})$ was further purified by preparative TLC on ordinary phase plates with $\mathrm{CHCl}_{3}$-acetone (4:1) to afford 2 (6.5 $\mathrm{mg}$ ). Fraction III $\mathrm{m} 5$ (124 mg) was recrystallized with $\mathrm{MeOH}$ to afford 3 (32 $\mathrm{mg})$.

SG-1 (tryprostatin $\mathrm{B}^{7-9)}$ ) (1): pale yellow crystalline powder, mp. $101-103{ }^{\circ} \mathrm{C}$ (lit. ${ }^{7-9)} 102-105{ }^{\circ} \mathrm{C}$ ). $[\alpha]_{\mathrm{D}^{19}}-77^{\circ}\left(\mathrm{c}=0.60, \mathrm{CHCl}_{3}\right)\left[\right.$ lit. $\left.^{7-9)}-71.1^{\circ} \quad\left(\mathrm{c}=0.63, \mathrm{CHCl}_{3}\right)\right]$. EI-MS $m / z(\%): 351\left(\mathrm{M}^{+}, 15\right), 198$ (100) [lit. $\left.{ }^{7-9)} 351\left(\mathrm{M}^{+}, 20\right), 198(100)\right]$. HREI-MS : $m / z 351.1956\left(\mathrm{C}_{21} \mathrm{H}_{25} \mathrm{~N}_{3} \mathrm{O}_{2}\right.$ requires 351.1946). UV $\lambda{ }_{\max }{ }^{\mathrm{MeOH}} \mathrm{nm}\left(\log \varepsilon\right.$ ): 224 (4.59), 273 (sh, 3.88), 283 (3.90), 290 (3.85) [lit. ${ }^{7.9)} 226$ (4.38), 277 (3.94), 298 (sh, 3.86)]. CD (0.71 mM, MeOH) $\Delta \varepsilon(\mathrm{nm}): 0.03$ (305), -0.15 (290), 0.27 (272), -0.04 (254), 6.55 (232), - 10.04 (210) [lit. ${ }^{7-9)} 0.3$ (303), 0.2 (292), 0.3 (272), 3.0 (232)]. ${ }^{1} \mathrm{H}$ - and ${ }^{13} \mathrm{C}-\mathrm{NMR}$ : see Table 1.

SG-2 (13-oxofumitremorgin B) (2): pale yellow amorphous powder, $[\alpha]_{D}^{19}+56^{\circ} \quad(\mathrm{c}=0.20$, $\mathrm{CHCl}_{3}$ ). EI-MS $m / z$ (\%): $477\left(\mathrm{M}^{+}, 12\right), 459$ (12), 310 (32), 309 (100), 241 (53). HREI-MS: $m / z$ $477.2246\left(\mathrm{C}_{27} \mathrm{H}_{31} \mathrm{~N}_{3} \mathrm{O}_{5}\right.$ requires 477.2263). UV $\lambda \max ^{\mathrm{MeOH}} \mathrm{nm}(\log \varepsilon): 218$ (sh, 4.42), 244 (sh, 4.13), 250 (4.16), 282 (4.06), 318 (sh,3.89). CD (1.05 mM, EtOH) $\Delta \varepsilon(\mathrm{nm}):-0.36$ (340), 3.23 (313), 1.12 (290), 1.93 (272), 1.03 (260), 1.70 (254), - 4.25 (244), 0.67 (233), -2.79 (226), 10.07 (210), 11.80 (204). ${ }^{1} \mathrm{H}-$ and ${ }^{13} \mathrm{C}-\mathrm{NMR}$ : see Table 2.

SG-3 (fumitremorgin $\left.\mathrm{B}^{10-12)}\right)(3)$ : white crystalline powder, $\mathrm{mp} 210-211^{\circ} \mathrm{C},[\alpha]_{\mathrm{D}^{19}}+31^{\circ}(\mathrm{c}=0.40$, $\left.\mathrm{CHCl}_{3}\right)$, EI-MS $m / z$ (\%): $479\left(\mathrm{M}^{+}, 87\right), 311$ (100), 268 (71). CD (1.05 mM, EtOH) $\Delta \varepsilon(\mathrm{nm}): 1.32$ (305), 1.40 (298), 1.20 (292), 2.75 (276), 2.13 (268), -0.91 (247) -0.77 (242), -1.92 (230), 0.71 (216), 0.27 (209). ${ }^{1} \mathrm{H}$ - and ${ }^{13} \mathrm{C}-\mathrm{NMR}$ : see Table 2 . This compound was identified with authentic sample of fumitremorgin $\mathrm{B}^{10-12)}$ in terms of mixed $\mathrm{mp}$, TLC behavior on ordinary phase plates with $\mathrm{CHCl}_{3-}$ acetone (5:1) and $\mathrm{C}_{6} \mathrm{H}_{6}$-EtOH (10:1), ${ }^{1} \mathrm{H}$ - and ${ }^{13} \mathrm{C}-\mathrm{NMR}$ ( in $\mathrm{CDCl}_{3}$ ), and $\mathrm{CD}$ spectra (in EtOH).

Oxidation of SG-3 (3) A solution of 3 (2 mg) in pyridine $(20 \mu \mathrm{l})$ was added to a complex 
prepared with $\mathrm{CrO}_{3}(5 \mathrm{mg})$ and pyridine $(30 \mu \mathrm{l})$ under ice-cooling, then the reaction mixture was stirred under ice-cooling for 1 hour and at room temperature for 4 hours. After addition of 1 drop of $\mathrm{MeOH}$, the mixture was diluted with water and extracted with $\mathrm{Et}_{2} \mathrm{O}$. The $\mathrm{Et}_{2} \mathrm{O}$ layer was treated as usual to give a product mixture, which was purified by a preparative TLC on an ordinary phase plate with $\mathrm{CHCl}_{3}$-acetone (5:1) to give a product tentatively named Oxo-SG-3 (0.5 mg) as amorphous powder. This product was identified with 2 in terms of TLC behavior on an ordinary phase plate with $\mathrm{CHCl}_{3}$-acetone (5:1), ${ }^{1} \mathrm{H}-\mathrm{NMR}$ (in $\mathrm{CDCl}_{3}$ ) (see Table 2) and $\mathrm{CD}$ spectra (in EtOH).

\section{Results and Discussion}

The AcOEt extract of $S$. gondaensis IFM45836) cultivated on sterilized rice suppressed by 99,91 , 77 , and $55 \%$ of the proliferation of mouse splenic lymphocytes stimulated with Con A (T cells) at 50 , $10,2.0$, and $0.4 \mu \mathrm{g} / \mathrm{ml}$, respectively. After separating $n$-hexane-soluble (fatty) portion, the extract was partitioned with AcOEt- $\mathrm{H}_{2} \mathrm{O}$. The AcOEt layer suppressed by $50 \%$ of the Con A-induced proliferation of the lymphocytes at less than $10 \mu \mathrm{g} / \mathrm{ml}$, while both the fatty portion and the aqueous layer suppressed it by $50 \%$ at more than $25 \mu \mathrm{g} / \mathrm{ml}$. Immunosuppressive activity-guided fractionation with repeated chromatography of the AcOEt layer afforded SG-1 (1), SG-2 (2), and SG-3 (3) as the immunosuppressive features of this fungus [yield (\%) from the AcOEt layer, 1: 4.2, 2: 0.058, and 3: $0.28]$.

SG-1 (1) was obtained as pale yellow crystalline powder, $\mathrm{C}_{21} \mathrm{H}_{25} \mathrm{~N}_{3} \mathrm{O}_{2}$, and was optically active. The ${ }^{1} \mathrm{H}$ - and ${ }^{13} \mathrm{C}$-NMR spectral data including the spin-decoupling ${ }^{1} \mathrm{H}-\mathrm{NMR}$, the two-dimensional ${ }^{1} \mathrm{H}-{ }^{1} \mathrm{H}$ shift correlation spectroscopy (COSY) NMR, ${ }^{1} \mathrm{H}$-detected heteronuclear correlation through multiple quantum coherence (HMQC) NMR, and ${ }^{1} \mathrm{H}$-detected heteronuclear multiple-bond correlation (HMBC) NMR (see Table 1) suggested that the structure of 1 quite resembled that of a cytotoxic dioxopiperazine, tryprostatin $\mathrm{B},{ }^{7-9)}$ isolated from Aspergillus fumigatus (see Chart 1). Comparison of the physicochemical and spectral data of SG-1 with those of tryprostatin B described in the literature ${ }^{7}$ 9) showed that SG-1 was identical with tryprostatin B (1) (see Table 1 and Materials and Methods).

SG-3 (3) was obtained as white crystalline powder, and was optically active. The physicochemical and spectral data including the ${ }^{1} \mathrm{H}$ - and ${ }^{13} \mathrm{C}-\mathrm{NMR}$ data of $\mathbf{3}$ were very similar to those of a tremorgenic dioxopiperazine, fumitremorgin $\mathrm{B},{ }^{10-12}$ isolated from Aspergillus fumigatus (see Table 2). SG-3 was identified with the authentic sample of fumitremorgin B (3) by direct comparison (see Chart 1). This is the first time that both tryprostatin B and fumitremorgin B have been isolated from S. gondaensis.

SG-2 (2) was obtained as pale yellow amorphous powder, $\mathrm{C}_{27} \mathrm{H}_{31} \mathrm{~N}_{3} \mathrm{O}_{5}$, and was optically active. Comparison of the ${ }^{1} \mathrm{H}$ - and ${ }^{13} \mathrm{C}$-NMR spectra of $\mathbf{2}$ with those of $\mathbf{3}$ exhibited that all of the signals in the ${ }^{1} \mathrm{H}$ - and ${ }^{13} \mathrm{C}$-NMR spectra of 2 were quite similar to those of $\mathbf{3}$ except for the disappearance of both signals of $\mathrm{H}-13$ and $\mathrm{OH}-13$ and the down-field shift of the signal of $\mathrm{C}-13$ to $\delta \mathrm{c} 182.13(+113.17)$, indicating that 2 might be a new compound having the structure of 13-oxo derivative of 3 . On oxidation of $\mathbf{3}$ with $\mathrm{CrO}_{3}$-pyridine complex, the hydroxyl group at position 13 in $\mathbf{3}$ was oxidized to give a 13-oxo derivative of $\mathbf{3}$, which was identified with $\mathbf{2}$ by direct comparison (see Materials and Methods). Thus, the structure of SG-2 was finally elucidated to be 13-oxofumitremorgin B (2).

The immunosuppressive activities ( $\mathrm{IC}_{50}$ values) of $\mathbf{1 - 3}$ were calculated against Con A- (T-cells) and LPS-induced (B-cells), and mitogen-free proliferations of mouse splenic lymphocytes, as shown in 
Table 1. $\quad{ }^{1} \mathrm{H}-\mathrm{NMR}$ and ${ }^{13} \mathrm{C}-\mathrm{NMR}$ data for SG-1 (1) and Typrostatin B (1) ${ }^{7-9)}, \delta(\mathrm{ppm})$ from TMS in $\mathrm{CDCI}_{3}$ (coupling constants in parentheses)

\begin{tabular}{|c|c|c|c|c|}
\hline \multirow[b]{2}{*}{ Position } & \multicolumn{2}{|l|}{ SG-1 } & \multicolumn{2}{|l|}{ Typrostatin $\mathrm{B}^{7-9)}$} \\
\hline & ${ }^{1} \mathrm{H}-\mathrm{NMR}$ & ${ }^{13} \mathrm{C}-\mathrm{NMR}$ & ${ }^{1} \mathrm{H}-\mathrm{NMR}$ & ${ }^{13} \mathrm{C}-\mathrm{NMR}$ \\
\hline 1-NH & 8.14 (brs) & & 8.03 (brs) & \\
\hline 2 & & $136.44(\mathrm{~s})$ & & $136.43(\mathrm{~s})$ \\
\hline 3 & & $104.51(\mathrm{~s})$ & & $104.61(\mathrm{~s})$ \\
\hline $3 a$ & & $127.93(\mathrm{~s})$ & & $127.97(\mathrm{~s})$ \\
\hline 4 & $7.47(\mathrm{~d}, 7.7)$ & $117.67(d)$ & $7.47(\mathrm{~d}, 7.7)$ & $117.74(\mathrm{~d})$ \\
\hline 5 & $7.09(\mathrm{t}, 7.7)$ & $119.81(\mathrm{~d})^{\mathrm{a})}$ & $7.09(\mathrm{t}, 7.7)$ & $119.91(d)$ \\
\hline 6 & $7.15(\mathrm{t}, 7.7)$ & $121.76(d)$ & $7.16(\mathrm{t}, 7.7)$ & $121.87(\mathrm{~d})$ \\
\hline 7 & $7.30(\mathrm{~d}, 7.7)$ & $110.75(d)$ & $7.31(\mathrm{~d}, 7.7)$ & 110.79 (d) \\
\hline $7 \mathrm{a}$ & & $135.31(\mathrm{~s})^{\mathrm{b})}$ & & $135.44(\mathrm{~s})$ \\
\hline 8 & $2.96(\mathrm{dd}, 15.1,11.2), 3.68(\mathrm{~m})$ & $25.58(t)$ & 2.96 (dd, 15.0, 11.0), 3.68 (dd, 15.0, 3.5) & $25.61(\mathrm{t})$ \\
\hline 9 & 4.37 (br dd, 11.2, 2.8) & 54.55 (d) & 4.37 (br dd, 11.0, 3.5) & $54.57(\mathrm{~d})$ \\
\hline $10-\mathrm{NH}$ & $5.67(\mathrm{brs})$ & & $5.64(\mathrm{brs})$ & \\
\hline 11 & & $169.31(\mathrm{~s})$ & & $169.35(\mathrm{~s})$ \\
\hline 12 & 4.05 (brt, 7.6) & 59.20 (d) & 4.06 (br dd, 8.0, 7.5) & 59.27 (d) \\
\hline 13 & $2.02(\mathrm{~m}), 2.32(\mathrm{~m})$ & $28.30(t)$ & $1.97-2.08(\mathrm{~m}), 2.33(\mathrm{~m})$ & $28.34(\mathrm{t})$ \\
\hline 14 & $1.90(\mathrm{~m}), 2.02(\mathrm{~m})$ & $22.57(\mathrm{t})$ & $1.85-1.95(\mathrm{~m}), 1.97-2.08(\mathrm{~m})$ & $22.64(\mathrm{t})$ \\
\hline 15 & $3.62(2 \mathrm{H}, \mathrm{m})$ & $45.36(t)$ & $\begin{array}{c}3.68 \text { (overlapped with } \mathrm{H}-8 \text { ) } \\
3.59 \text { (ddd, } 12.0,8.5,3.0 \text { ) }\end{array}$ & $45.41(\mathrm{t})$ \\
\hline 17 & & $165.76(\mathrm{~s})$ & & $165.80(\mathrm{~s})$ \\
\hline 18 & $3.46(2 \mathrm{H}, \mathrm{m})$ & $25.07(\mathrm{t})$ & $3.44(\mathrm{dd}, 17.0,6.5), 3.49(\mathrm{dd}, 17.0,7.0)$ & $25.12(\mathrm{t})$ \\
\hline 19 & 5.30 (brt, 7.2 ) & $119.74(d)^{a)}$ & $5.31(\mathrm{br} \mathrm{dd}, 7.0,6.5)$ & $119.70(d)$ \\
\hline 20 & & $135.41(\mathrm{~s})^{\mathrm{b})}$ & & $135.48(\mathrm{~s})$ \\
\hline 21 & $1.77(3 \mathrm{H}, \mathrm{s})$ & $25.68(q)$ & $1.79(3 \mathrm{H}, \mathrm{s})$ & $25.74(q)$ \\
\hline 22 & $1.74(3 \mathrm{H}, \mathrm{s})$ & $17.92(q)$ & $1.75(3 \mathrm{H}, \mathrm{s})$ & $17.98(q)$ \\
\hline
\end{tabular}

a),b) : interchangeable

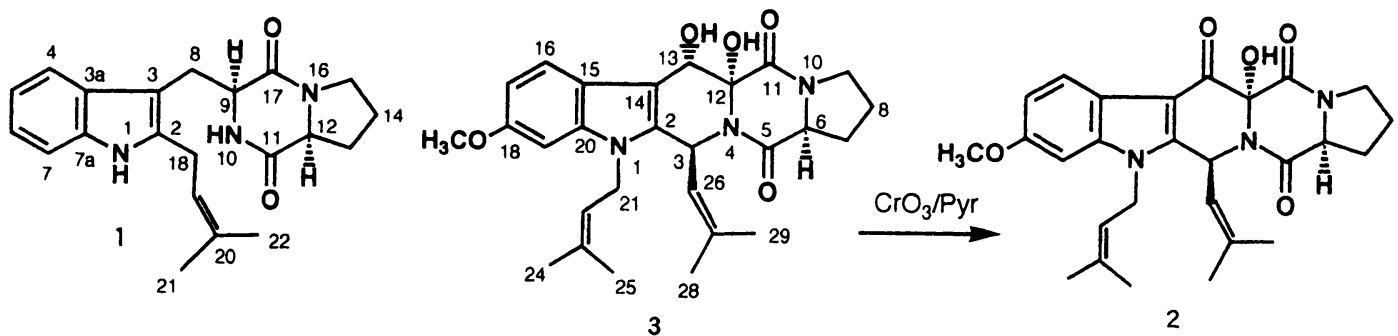<smiles>C=CC(C)(C)c1[nH]c2c(CC=C(C)C)cc(CC=C(C)C)cc2c1C[C@]1(C)NC(=O)[C@H](C)NC(=O)[C@]1(C)Cc1c(C(C)(C)C=C)[nH]c2c(CC=C(C)C)cccc12</smiles>

Chart 1 
Table 2. ${ }^{1} \mathrm{H}-\mathrm{NMR}$ and ${ }^{13} \mathrm{C}-\mathrm{NMR}$ data for SG-2 (2), SG-3 (3) and Oxo-SG-3 (2), $\delta(\mathrm{ppm})$ from TMS in $\mathrm{CDCl}_{3}$ (coupling constants in parentheses)

\begin{tabular}{|c|c|c|c|c|c|}
\hline \multirow[b]{2}{*}{ Position } & \multicolumn{2}{|l|}{ SG-2 } & \multicolumn{2}{|l|}{ SG-3 } & \multirow{2}{*}{$\begin{array}{l}\text { Oxo-SG-3 } \\
{ }^{1} \mathrm{H}-\mathrm{NMR}\end{array}$} \\
\hline & ${ }^{1} \mathrm{H}-\mathrm{NMR}$ & ${ }^{13} \mathrm{C}-\mathrm{NMR}$ & ${ }^{1} \mathrm{H}-\mathrm{NMR}$ & ${ }^{13} \mathrm{C}-\mathrm{NMR}$ & \\
\hline 2 & & $147.59(\mathrm{~s})$ & & $131.14(\mathrm{~s})$ & \\
\hline 3 & $6.07(\mathrm{~d}, 9.6)$ & $48.60(\mathrm{~d})$ & $5.97(\mathrm{~d}, 10.0)$ & $49.02(\mathrm{~d})$ & $6.08(\mathrm{~d}, 9.8)$ \\
\hline 5 & & $165.70(\mathrm{~s})$ & & $166.22(\mathrm{~s})$ & \\
\hline 6 & $4.72(\mathrm{t}, 8.3)$ & $60.00(\mathrm{~d})$ & $4.45(\mathrm{dd}, 9.6,7.1)$ & 58.74 (d) & $4.76(\mathrm{t}, 8.3)$ \\
\hline 7 & $2.15(\mathrm{~m}), 2.33(\mathrm{~m})$ & $28.60(\mathrm{t})$ & $1.94(\mathrm{~m}), 2.47(\mathrm{~m})$ & $28.93(t)$ & $2.10(\mathrm{~m}), 2.38(\mathrm{~m})$ \\
\hline 8 & $1.88(\mathrm{~m}), 2.04(\mathrm{~m})$ & $23.11(\mathrm{t})$ & $2.08(2 \mathrm{H}, \mathrm{m})$ & $22.59(\mathrm{t})$ & $1.92(2 \mathrm{H}, \mathrm{m})$ \\
\hline 9 & $3.55(2 \mathrm{H}, \mathrm{m})$ & $45.54(\mathrm{t})$ & $3.63(2 \mathrm{H}, \mathrm{dd}, 9.0,4.6)$ & $45.24(\mathrm{t})$ & $3.53(\mathrm{~m}), 3.62(\mathrm{~m})$ \\
\hline 11 & & $172.66(\mathrm{~s})$ & & $170.45(\mathrm{~s})$ & \\
\hline 12 & & $81.66(\mathrm{~s})$ & & $82.94(\mathrm{~s})$ & \\
\hline $12-\mathrm{OH}$ & & & 4.05 (brs) & & \\
\hline 13 & & $182.13(\mathrm{~s})$ & $5.77(\mathrm{~d}, 2.7)$ & 68.96 (d) & \\
\hline $13-\mathrm{OH}$ & & & 4.71 (brd, 2.7) & & \\
\hline 14 & & $108.21(\mathrm{~s})$ & & $104.38(\mathrm{~s})$ & \\
\hline 15 & & $118.54(\mathrm{~s})$ & & $120.51(\mathrm{~s})$ & \\
\hline 16 & $8.13(\mathrm{~d}, 8.7)$ & $123.02(\mathrm{~d})$ & $7.85(\mathrm{~d}, 8.7)$ & $121.34(\mathrm{~d})$ & $8.20(\mathrm{~d}, 8.7)$ \\
\hline 17 & $6.80(\mathrm{dd}, 8.7,2.0)$ & $111.68(\mathrm{~d})$ & $6.80(\mathrm{dd}, 8.7,2.2)$ & 109.29 (d) & $6.96(\mathrm{dd}, 8.8,2.1)$ \\
\hline 18 & & $157.74(\mathrm{~s})$ & & $156.19(\mathrm{~s})$ & \\
\hline $18-\mathrm{OCH}_{3}$ & $3.82(3 \mathrm{H}, \mathrm{s})$ & $55.64(q)$ & $3.84(3 \mathrm{H}, \mathrm{s})$ & $55.72(\mathrm{q})$ & $3.86(3 \mathrm{H}, \mathrm{s})$ \\
\hline 19 & $6.70(\mathrm{~d}, 2.0)$ & 94.90 (d) & $6.69(\mathrm{~d}, 2.2)$ & $93.85(d)$ & $6.72(\mathrm{~d}, 2.0)$ \\
\hline 20 & & $139.01(\mathrm{~s})$ & & $137.88(\mathrm{~s})$ & \\
\hline 21 & 4.48 (dd, 16.1, 4.3), 4.55 (dd, 16.1, 6.7) & $42.67(\mathrm{t})$ & $4.54(2 \mathrm{H}, \mathrm{brd}, 5.6)$ & $41.77(\mathrm{t})$ & $4.53(\mathrm{dd}, 16.6,5.4), 4.60(\mathrm{dd}, 16.6,6.8)$ \\
\hline 22 & 4.99 (brt, 5.5) & $118.54(d)$ & $5.03(\mathrm{brt}, 5.6)$ & $120.27(\mathrm{~d})$ & $5.02(\mathrm{brt}, 5.7)$ \\
\hline 23 & & $136.33(\mathrm{~s})$ & & $134.58(\mathrm{~s})$ & \\
\hline 24 & $1.84(3 \mathrm{H}, \mathrm{s})$ & $18.33(q)$ & $1.85(3 \mathrm{H}, \mathrm{s})$ & $18.18(q)$ & $1.87(3 \mathrm{H}, \mathrm{s})$ \\
\hline 25 & $1.71(3 \mathrm{H}, \mathrm{s})$ & $25.56(q)$ & $1.70(3 \mathrm{H}, \mathrm{s})$ & $25.68(\mathrm{q})$ & $1.74(3 \mathrm{H}, \mathrm{s})$ \\
\hline 26 & $4.77(\mathrm{~d}, 9.6)$ & $122.36(d)$ & $4.70(\mathrm{~d}, 10.0)$ & $122.96(d)$ & $4.83(\mathrm{~d}, 10.1)$ \\
\hline 27 & & $137.99(\mathrm{~s})$ & & $135.20(\mathrm{~s})$ & \\
\hline 28 & $1.95(3 \mathrm{H}, \mathrm{s})$ & $18.76(q)$ & $1.99(3 \mathrm{H}, \mathrm{s})$ & $18.35(q)$ & $1.97(3 \mathrm{H}, \mathrm{s})$ \\
\hline 29 & $1.63(3 \mathrm{H}, \mathrm{s})$ & 25.56 (q) & $1.63(3 \mathrm{H}, \mathrm{s})$ & $25.51(q)$ & $1.66(3 \mathrm{H}, \mathrm{s})$ \\
\hline
\end{tabular}

Table 3. The $\mathrm{IC}_{50}$ values of three related dioxopiperazines, tardioxopiperazines $\mathrm{A}(4)$ and $\mathrm{B}(5)$ from Microascus tardifaciens, 5) and echinuline (6) from Aspergillus echinulatus and other Aspergillus glaucus group fungi ${ }^{13-15)}$ (see Chart 1), and some positive controls against Con A- and LPS-induced, and mitogen-free proliferations of the lymphocytes are also shown in Table 3. Among these six dioxopiperazines, 1-4 show moderate immunosuppressive activity, while 5 and 6 show slight one. The fact that the activity of $\mathbf{2}$ is a little higher than that of $\mathbf{3}$ suggests that substitution of a hydroxyl group at position 13 in 3 by a carbonyl group slightly increases the activity. It has been already known that 1 and 3 possess inhibitory activity against the cell cycle progression of mouse tsFT210 cells in the M phase. $^{7-9)}$ The immunosuppressive activity of 1,2 , and 3 seem to be connected with their cytotoxic property.

Acknowledgement We are grateful to Miss R. Hara of Analysis Center, Chiba University for HREI-MS measurement. 
Table 3. Immunosuppressive effects of SG-1 (1) - -3 (3), and some related compounds on the Con A- induced, LPS-induced and mitogen-free proliferations of mouse splenic lymphocytes

\begin{tabular}{cccc}
\hline & \multicolumn{2}{c}{$\mathrm{IC}_{50}(\mu \mathrm{g} / \mathrm{ml})$} & \\
Compound & Con A-Induced & LPS-Induced & Mitogen-Free \\
\hline $\mathbf{1}$ & 12 & 3.0 & 6.0 \\
$\mathbf{2}$ & 2.3 & 0.4 & 1.5 \\
$\mathbf{3}$ & 7.0 & 0.8 & 2.9 \\
Tradioxopiperazine A (4) & 4.5 & 0.7 & 0.4 \\
Tradioxopiperazine B (5) & $>25$ & 15 & 0.8 \\
Echinuline (6) & $>25$ & 8.0 & 11.8 \\
Azathipurine & 2.7 & 2.7 & not.tested \\
Cyclosporin A & 0.04 & 0.07 & 0.05 \\
FK506 (Tacrolimus) & $0.015 \times 10^{-3}$ & $1.6 \times 10^{-3}$ & $2.1 \times 10^{-3}$ \\
\hline
\end{tabular}

\section{References and Notes}

1 ) Fujimoto, H., Satoh, Y., Nakayama, M., Takayama, T., Yamazaki, M. : Chem. Pharm. Bull., 43, 547-552 (1995).

2 ) Fujimoto, H., Sumino, M., Nagano, J., Natori, H., Okuyama, E., Yamazaki, M. : Chem. Pharm. Bull., 47, 71-76 (1999).

3 ) Fujimoto, H., Satoh, Y., Yamazaki, M. : Chem. Pharm. Bull., 46, 211-216 (1998).

4 ) Fujimoto, H., Nagano, J., Yamaguchi, K., Yamazaki, M. : Chem. Pharm. Bull., 46, 423-429 (1998).

5 ) Fujimoto, H., Fujimaki, T., Okuyama, E., Yamazaki, M. : Chem. Pharm. Bull., 47, 1426-1432 (1999).

6 ) This strain was deposited earlier at Research Institute for Chemobiodynamics, Chiba University (present name: Research Center for Pathogenic Fungi and Microbial Toxicoses, Chiba University). Now, the voucher specimen is also on deposit in our laboratory.

7 ) Cui, C. B., Kakeya, H., Okada, G., Onose, R., Ubukata, M., Takahashi, I., Isono, K., Osada, H. : J. Antibiot., 48, 1382-1384 (1995).

8 ) Cui, C. B., Kakeya, H., Okada, G., Onose, R., Osada, H. : J. Antibiot., 49, 527-533 (1996).

9 ) Cui, C. B., Kakeya, H., Osada, H. : J. Antibiot., 49, 534-540 (1996).

10) Yamazaki, M., Fujimoto, H., Akiyama, T., Sankawa, U., litaka, Y. : Tetrahedron Lett., 1975, 27-28.

11) Yamazaki, M., Fujimoto, H., Kawasaki, T. : Chem. Pharm. Bull., 28, 245-254 (1980).

12) Yamazaki, M., Suzuki, K., Fujimoto, H., Akiyama, T., Sankawa, U., Iitaka, Y. : Chem. Pharm. Bull., 28, 861-865 (1980).

13) Quilico, A., Panizzi, L. : Chem. Ber., 76, 348-358 (1943).

14) Nakashima, R., Slater, G. P. : Tetrahedron Lett., 1971, 2649-2650.

15) Fujimoto, H. : Annual Report of Research Institute for Chemobiodynamics, Chiba University, 5, 9-43 (1977). 


\section{子襄菌 Sordaria gondaensis の免疫抑制活性成分}

藤本治宏, 藤巻利之, 奥山恵美, 山崎幹夫：下葉大学薬学部 (263-8522 千葉市稲毛区弥生町1-33)

免疫調節活性を指標とした子襄菌Sordaria gondaensisの酢酸エチル抽出エキスの分画において，3種のジ オキソピペラジン系成分が, 本菌の免疫抑制活性本体として単離された。それらは，2種の既知菌類代謝産 物, トリプロスタチンBとフミトレモルジン B, 並びに1種の新代謝産物, 13-オキソフミトレモルジン B, であることを，それらの物性とスペクトルデータ抢よび化学的関連付けから明らかにした。トリプロス夕 チンBとフミトレモルジンBが本菌から単離されたのは。今回が初めてである.

キーワード：子囊菌，免疫抑制物質，2，5-ジオキソピペラジン，13-オキソフミトレモルジンB 